\title{
Operating Conditions Dependence of the Junction Characteristics of Optocouplers
}

\author{
W. Abdelbasit * (1), W.H.A. Hassan ${ }^{(1)}$, F. A. S. Soliman ${ }^{(2)}$, and S. A. Kamh ${ }^{(1)}$ \\ 1-Electronic Research Lab., Physics Dept., Faculty of Women for Arts, \\ Science, and Education, Ain-Shams University, Cairo, Egypt. \\ 2- Nuclear Materials Authority, P.O.Box 530, Maadi-11728, Cairo, Egypt.
}

\begin{abstract}
The present paper is a trial to shed further light on the dependence of the junction characteristics of the proposed optocoupler type $4 \mathrm{~N} 25$ on the operating conditions; the applied voltage and signal frequency. For the input light emitting diode and output phototransistor, their forward and reverse $(\mathrm{C}-\mathrm{V})$ characteristics were investigated and plotted at different applied bias voltage- and frequency- levels. In this concern, the diffusion- and transition- capacitances, impedance, quality- and dissipation- factors, and the phase angle were investigated. Concerning the light emitting diode, at frequency value of $200 \mathrm{kHz}$, as an example, the diffusion capacitance value increases exponentially from $0.166 \mathrm{nF}$, up to 4.71 $\mathrm{nF}$, measured at forward bias voltages of 0.01 Volt and 1.20 Volts, respectively. Also, at an applied forward bias voltage of 1.0 Volts, the diffusion capacitance increases from $1.76 \mathrm{nF}$ up to $2.84 \mathrm{nF}$, measured at frequency levels of $50 \mathrm{kHz}$ and $300 \mathrm{kHz}$, respectively. Considering the transition capacitance, and at signal frequency of $200 \mathrm{kHz}$, its value was shown to be decreased rapidly from $178.36 \mathrm{pF}$ down to $30.42 \mathrm{pF}$ whenever measured at 0.01 Volt and 0.30 Volt, respectively. But for higher bias voltages, the decreasing rate was shown to be negligible. On the other hand, at applied bias voltage of 1.0 Volt, its value was shown to be decreased from $28.76 \mathrm{pF}$ down to $17.59 \mathrm{pF}$, measured at frequency levels of $50 \mathrm{kHz}$ and 300 $\mathrm{kHz}$. For the phototransistor, its emitter junction capacitance increased exponentially as a function of the emitter-base bias voltage, where at frequency of $200 \mathrm{kHz}$, as an example, its value increased from $0.581 \mathrm{nF}$ up to $3.048 \mathrm{nF}$, measured at 0.01 Volt and 0.80 Volt, respectively. On the other hand, the collector junction capacitance was shown to be decayed rapidly as a function of the applied reverse bias voltage. Where its value decreased from 1.29 $\mathrm{nF}$ down to $0.012 \mathrm{nF}$, measured at 0.01 Volt and 0.90 Volt, at frequency of $200 \mathrm{kHz}$, as an example. Finally, it is proved that for both capacitances, their values are a direct decreasing functions of the operating frequency, where at applied bias voltage of 0.8 Volt, a values of $7.6878 \mathrm{nF}$ and $0.05338 \mathrm{nF}$ were decreased down to $1.811 \mathrm{nF}$ and $0.0254 \mathrm{nF}$, respectively, with increasing the frequency from $50 \mathrm{kHz}$ up to $300 \mathrm{kHz}$.
\end{abstract}

Keywords: Capacitance-voltage characteristics, quality factor, dissipation factor, phase-angle optocoupler, light emitting diode, phototransistor and impedance.

\section{Introduction}

\subsection{Description of the Optocouplers}

An opto-coupler (opto-electronic coupler) is essentially a photo-transistor/photo-diode and a Light Emitting Diode (LED) combined in one package, emerging optocoupler (Reed, et

*Corresponding author: E-mail address: wafaazekri2006@yahoo.com

al., 1998, Yao, et al., 2007, Chin Wey, et al., 2013, Lei Tian, et al., 2014 and Chouthai, et al., 2013). The input of an optocoupler consists of an infra-red LED die; while, its output consists 
of a detector die which typically is a photo bipolar NPN transistor. The input and output dice are separated by an electrically insulated material which is transparent to infrared light. The input and output components and their light transmitting medium are encased in molded plastic, metal can or ceramic enclosure. In this concern, the optocouplers of the type 4N25 were investigated throughout the study, where, Fig. (1) shows their circuit description and pin out (Eugene, et al., 2009). The 4N25 comes in a 6-pin dual inline package (DIP) and contains a gallium-arsenide light emitting diode and a silicon bipolar phototransistor coupled vertically meaning that the LED is directly on top of the phototransistor.
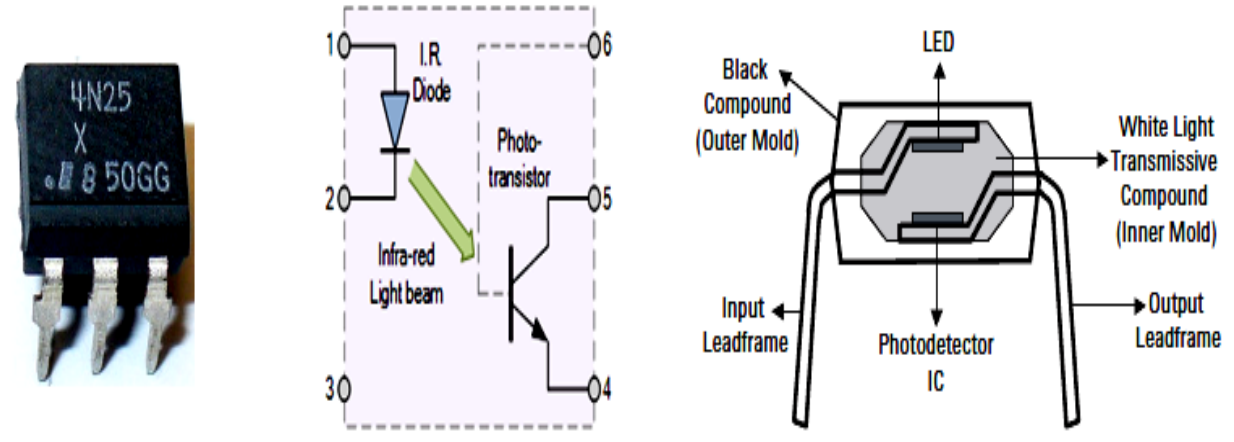

Fig. (1): The 4N25 optocoupler and its pin diagram.

\subsection{Operating Principles of the Optocoupler}

Optocouplers operate on the principle that light can be emitted, transmitted, and absorbed by a semiconductor to communicate signals optically (Reed, et al., 2004). The optical signal electrically isolates the microelectronic circuits on either side of the optocoupler (Fig. 2). From which, when the current flows in the LED, it emits infrared light, goes through the insulation material and detected by the collector base region of the phototransistor. Where an electron hole pairs is generates in the collector base region resulting in a photo current flowing into the base of the bipolar transistor. This photo current is multiplied by the current gain, beta, of the bipolar transistor to produce an output collector current. A current transfer ratio, CTR, of an optocoupler is defined as the ratio of the output collector current over the current flowing in the infrared LED (Eugene, et al., 2009).

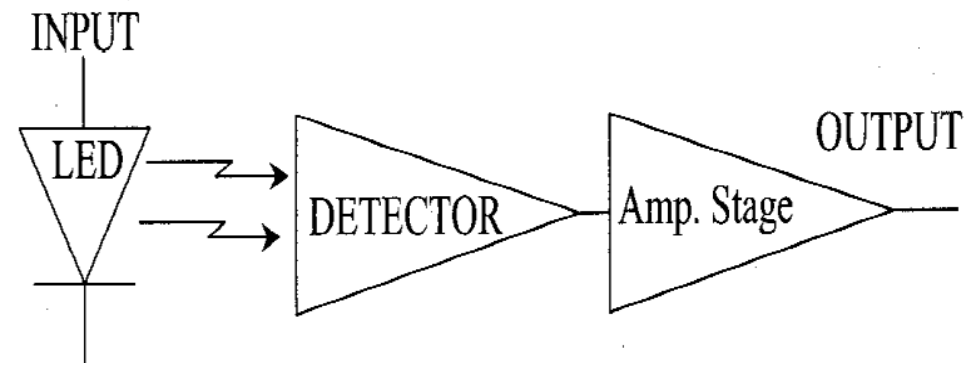

Fig. (2): Typical Optocoupler design.

\subsection{Importance of Junction Characteristics Studies}


Capacitance-voltage profiling is a technique for characterizing semiconductor materials and devices. The depletion region in the junction devices with its ionized charges inside behaves like a capacitor. So, by varying the voltage applied to the junction it is possible to vary the depletion width. The dependence of the depletion width upon the applied voltage provides information on the semiconductor's internal characteristics, such as its doping profile and electrically active defect densities. Measurements may be done at DC, or using both DC and a small-signal AC signal (the conductance method), or using a large-signal transient voltage. Besides, $(\mathrm{C}-\mathrm{V})$ measurements are widely used to characterize wide spectrum of semiconductor devices and technologies, including bipolar junction transistors, JFETs, III-V compound devices, photovoltaic cells, MEMS devices, organic thin-film transistor (TFT) displays, photodiodes, and carbon nano-tubes (CNTs). Finally, the junction capacitance may be used to measure doping concentration in the semiconductor side of a diode as well as determining the built-in potential and junction area of a device (Dutta, et al., 2013). In the present paper, both the diffusion- and transition- capacitances $\left(C_{D}\right.$, and $\left.C_{T}\right)$, the impedance $(Z)$, quality- and dissipation- factors $(Q, D)$, and phase angle $(\Phi)$ of the input LED and output phototransistor of optocoupler were investigated.

\subsection{Materials and Methods}

During the course of the present paper a detailed study concerning the dependence of the junction characteristics of the input LED and output phototransistor of the proposed optocoupler type $4 \mathrm{~N} 25$ on the operating voltage and frequency was carried out. In this concern, the following parameters: $\mathrm{C}_{\mathrm{D}}, \mathrm{C}_{\mathrm{T}}, \mathrm{Z}, \mathrm{Q}, \mathrm{D}$ and $\Phi$ were investigated and plotted as a function of the applied bias voltage ranging from 0.01 Volt up to 1.2 Volts (forward and reverse), with different frequency levels ranging from $50 \mathrm{kHz}$ up to $300 \mathrm{kHz}$ using a programmable automatic LCR meter type PM-6306, manufactured by Fluke.

\subsection{Results and Discussions}

\section{1 (C-V) Characteristics of Input LED}

\subsubsection{Diffusion - and - Transition Capacitances}

The diffusion -and transition -capacitances were given in Eqs. (1 and 2), respectively (Boylestad, et al., 1999 and Bogdan, et al., 2011):

$$
C_{d i f}=\frac{d Q}{d V}=\frac{d}{d V}\left[\tau I_{o} \exp \left(\frac{V}{\eta V_{T}}\right)\right]=\frac{\tau I_{B}}{\eta V_{T}}
$$

Where:

Q : total storage charge at the junction $=\mathrm{I}_{\mathrm{B}} \tau$,

$\tau$ : storage time,

$\mathrm{I}_{\mathrm{B}}$ : diode base current, and

$\eta$ : correction factor has a value between 1 and 2 .

$$
C_{T}=\frac{\varepsilon A}{W}
$$

Where: 
A : junction area,

$\varepsilon:$ dielectric permittivity of semiconductor material, and

$\mathrm{W}$ : thickness of the depletion layer.

Figure (3) shows the dependence of both the diffusion $\left(\mathrm{C}_{\mathrm{D}}\right)$ - and transition $\left(\mathrm{C}_{\mathrm{T}}\right)$ capacitances on the applied bias voltage, plotted at different signal frequency levels. From which, it is clear that, both capacitances are functions of the applied voltage and the frequency. Considering, the diffusion capacitance (Fig. 3a), its value is a function of the diode current, storage time $\tau$, and diode biasing current $\mathrm{I}_{\mathrm{B}}$, as given from Eq.1 (Bogdan, et al., 2011 and El - Ghanam and Abdel Basit, 2011). At frequency value of $200 \mathrm{kHz}$, as an example, the diffusion capacitance value increases exponentially from $0.166 \mathrm{nF}$, up to 4.71 $\mathrm{nF}$, measured at the forward bias voltages of 0.01 Volt and 1.20 Volts, respectively. Also, at a certain value of the applied forward bias voltage of around 1.0 Volts, the diffusion capacitance increases from $1.76 \mathrm{nF}$ up to $2.84 \mathrm{nF}$, measured at frequency levels of $50 \mathrm{kHz}$ and $300 \mathrm{kHz}$, respectively. On the other hand, for the reverse-bias voltage (Fig. 3b), and at frequency of $200 \mathrm{kHz}$, as an example, $\mathrm{C}_{\mathrm{T}}$ decreased rapidly from $178.36 \mathrm{pF}$ down to 30.42 $\mathrm{pF}$, measured at lower bias voltage less than 0.3 Volt. For higher voltage values, up to 1.2 Volts, its value was shown to be almost constant. The matter which is attributed to the existence of depletion region which behaves essentially like an insulator. Since the depletion width (w) will increase with increased reverse-bias potential, the resulting transition capacitance will decrease, as given from Eq.2 (Boylestad, et al., 1999). At a certain Value of a reverse applied voltage of 1.0 Volts, $\mathrm{C}_{\mathrm{T}}$ decreased from $28.76 \mathrm{pF}$ to $17.59 \mathrm{pF}$ measured at frequency levels of $50 \mathrm{kHz}$ and $300 \mathrm{kHz}$.

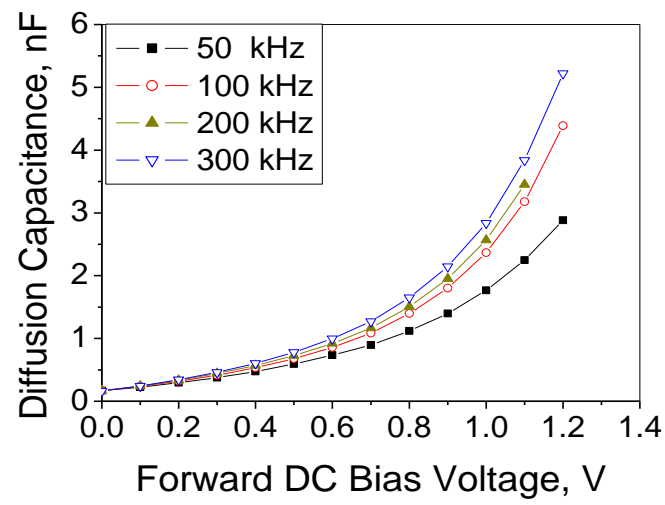

(a)

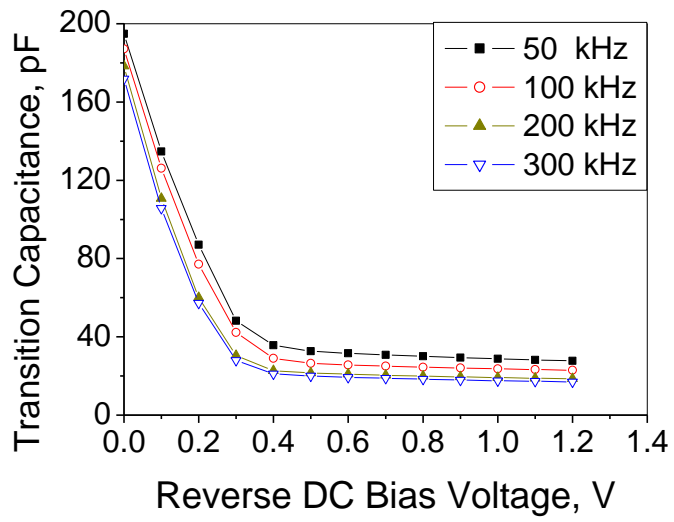

(b)

Fig. (3): Dependence of the diffusion (a) - and transition (b) - capacitances on the applied voltage, plotted at different signal frequency values.

\subsubsection{Impedance}

It is well known that the impedance of a circuit is defined as the ratio of the phasor voltage and the phasor current (Kim, et al., 2011). In this concern, considering the input LED, the dependence of its impedance on bias voltage in either the forward - or reverse - bias voltages were investigated and plotted at wide signal frequency band ranging from values of $50 \mathrm{kHz}$ up to $300 \mathrm{kHz}$ (Fig. 4). For the forward bias conditions, the impedance was proved to

be function, only, on the forward bias voltage rather than the signal frequency (Fig. 4a), where its value decreases from $1.50 \mathrm{k} \Omega$, measured at bias voltage 0.01 Volt, down to $0.02 \mathrm{k} \Omega$, 
measured at bias Voltage of 1.20 Volts (at $\mathrm{f}=200 \mathrm{kHz}$, as an example). On the other hand, the reverse impedance (Fig. 4b) was shown to be function of both the applied reverse bias and frequency. For low reverse bias voltages value, up to around 0.30 Volts, the impedance was shown to be with weak dependence of the applied bias, while its value is independent of the frequency. For intermediate bias voltages, from 0.3 Volt up to around 0.7 Volt a rapid increase on the impedance value was observed, depending on the applied signal frequency. Finally, for higher bias voltages, a saturation or semi-saturation on the impedance value was recorded.

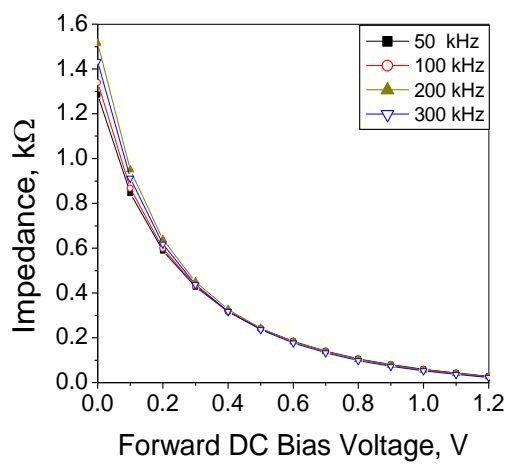

(a)

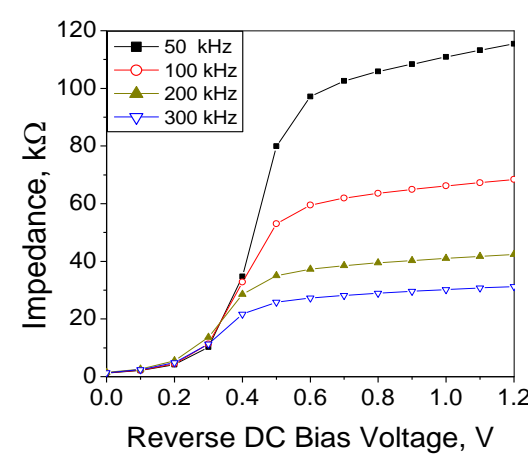

(b)

Fig. (4): Dependence of LED impedance on (a) forward-bias voltage and (b) reverse-bias voltage, plotted at different signal frequencies.

\subsubsection{Quality Factors}

Another important parameter of a capacitance diode is the quality factor (Q), which also called figure of merit, the value which should be high (Godse, et al., 2008). The quality factor of a reactive element either capacitor or inductor is the ratio of energy stored and returned by the element to the energy dissipated in the device resistance. Also, Q of a resonator can be defined as the ratio of the energy stored in a system to the energy dissipated per radian of the vibration cycle. Finally, Q can be expressed as (Hopcroft, et al., 2007):

$$
Q=2 \pi \frac{E_{\text {stored }}}{E_{\text {dissipatedl cycle }}}
$$

At high frequency levels, Q of a parallel capacitance diode could be expressed as (El Ghanam and Abdel Basit, 2011):

$$
Q=2 \pi f C R
$$

Where:

$\mathrm{f}$ : frequency of the applied voltage,

$\mathrm{C}$ : equivalent parallel capacity, and

$\mathrm{R}$ : equivalent parallel resistance.

As deduced from Equ. (4), Q factor of a capacitance diode varies with the reverse bias; this is because the diode capacitance decreases as the reverse voltage is increased; $Q$ is also 
dependent on frequency. As shown in (Fig. 5), Q factor plotted as a function of forward and reverse bias voltage at different signal frequency levels. For forward bias voltage (Fig. 5a), Q factor decreased from 0.334 down to 0.158 measured at bias voltage value of 0.01 Volt and 1.2 Volts, at signal frequency of $200 \mathrm{kHz}$, as an example. On the other hand, for reverse bias voltage (Fig. 5b) increase from 0.01 Volt up to 0.6 Volt, Q factor increase from 0.368 up to 2.65, at $\mathrm{F}=200 \mathrm{kHz}$, as an Example, as the bias voltage increased up to 1.2 Volts, the $\mathrm{Q}$ factor almost constant. At a certain value of voltage (1.0 volts), as an example, $Q$ factor of both forward and reverse bias voltage increased from 0.043 and 2.5656 up to 0.297 and 3.12, respectively, measured at a signal frequency value of $50 \mathrm{kHz}$ and $300 \mathrm{kHz}$.

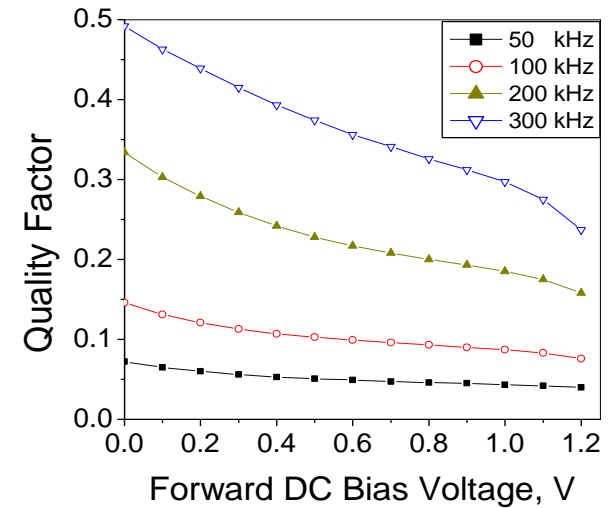

(a)

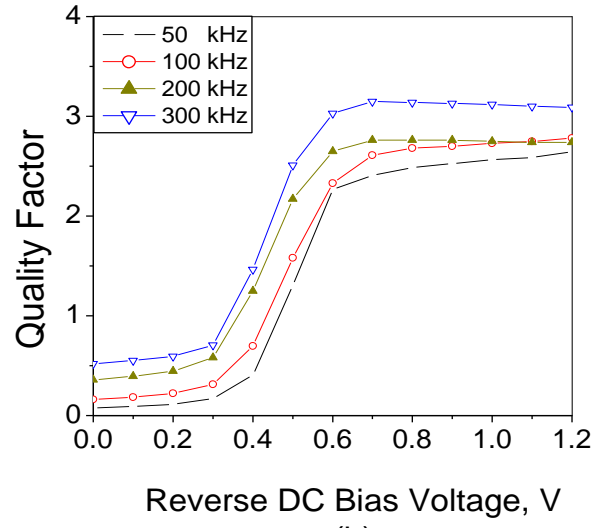

(b)

Fig. (5): Dependence of LED quality factor on (a) forward-bias voltage and (b) reverse-bias voltage, plotted at different signal frequency values.

\subsubsection{Dissipation Factor}

In principle, the dissipation factor (D) is simply the reciprocal of the $\mathrm{Q}$ factor, which in general could be expressed as (Rodahl, et al., 1995):

$$
D=\frac{1}{Q}=\frac{E_{\text {dissipatedl cycle }}}{2 \pi E_{\text {stored }}}
$$

An ideal capacitor stores energy without dissipating any power. However, due to equivalent resistances $\left(\mathrm{R}_{\mathrm{eq}}\right)$, some power will be dissipated. So, one important characteristics of a capacitance diode the dissipation factor (D), which is expressed as (Dyer, 2001):

$$
D=\tan \delta=\frac{R_{e q}}{X_{e q}}
$$

Where:

$\delta$ : angle of loss, and

$\mathrm{X}_{\mathrm{eq}}$ : equivalent reactance

For the capacitor, $\mathrm{D}$ is related to the parallel resistance, $\mathrm{R}$ by: 


$$
D=\frac{1}{Q}=\frac{1}{2 \pi f C R}
$$

From which, it is clearly shown that $\mathrm{D}$ is a direct function of both the applied voltage and signal frequency. A typical D curve of LED of optocoupler type 4N25 in the forward and reverse - bias voltages, plotted at different signal frequency levels is depicted in Fig. (6). For forward bias voltage (Fig. 6a), D factor increased from 2.93 up to 5.92 measured at bias voltage value of 0.01 Volt and 1.2 Volts, at signal frequency of $200 \mathrm{kHz}$, as an example. At a certain value of voltage (1.0 volts), as an example, D factor of the forward bias voltage decreased from 21.5 down to 3.21 , measured at a signal frequency value of $50 \mathrm{kHz}$ and 300 $\mathrm{kHz}$. On the other hand, for reverse bias voltage (Fig. 5b), from 0.01 Volt up to 0.5, D factor value was shown to be decrease from 2.8 down to 0.46, at $\mathrm{F}=200 \mathrm{kHz}$, as an Example, as the bias voltage increased up to 1.2 Volts, D factor almost constant. At lower bias voltage up to 0.5 Volt, D factor decreased as the signal frequency value increased, but for higher voltage up to 1.2 Volts, the $\mathrm{D}$ factor almost constant.

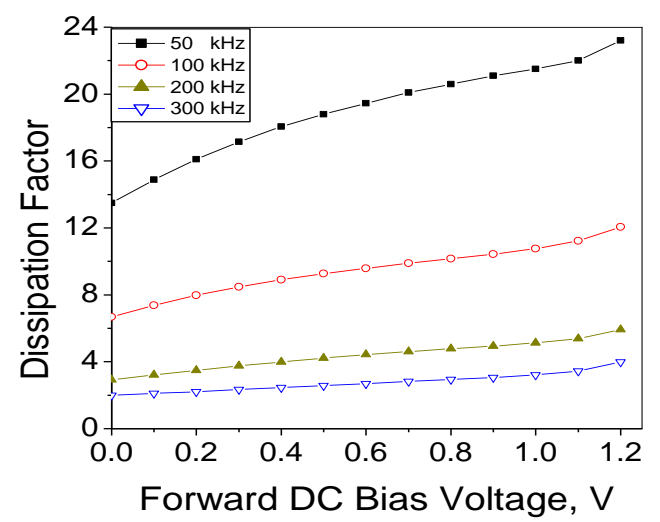

(a)

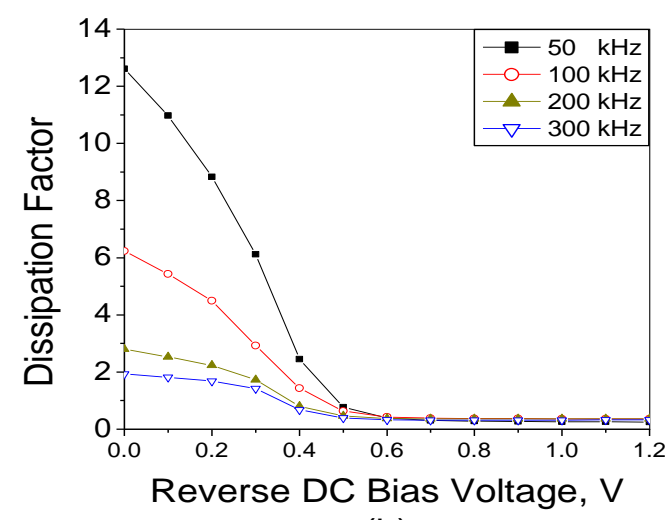

(b)

Fig. (6): Dependence of LED dissipation factor on forward (a)- and reverse (b)-bias voltages, plotted at different signal frequency values.

\subsubsection{Phase Angle}

It is well known that with reactive elements there will be a phase shift between the current and voltage. For a pure capacitive load the current will lead the voltage by $90^{\circ}$ and for a pure inductive load the current will lag the voltage by $90^{\circ}$. With a mixture of resistive and reactive loads the phase angle will be somewhere between $+90^{\circ}$ and $-90^{\circ}$, either leading or lagging (El - Ghanam and Abdel Basit, 2011).In this concern, the nature of the variation of phase angles as a function of the both the forward and reverse bias voltage is shown in Fig. (7). For forward bias voltage (Fig.7a), the phase angle increased from $-18.9^{\circ}$ up to $-9.6^{\circ}$ measured at bias voltage value of 0.01 Volt and 1.2 Volts, at signal frequency of $200 \mathrm{kHz}$, as an example. On the other hand, for the case of the reverse biased voltage (Fig. 7b), as its value increases from $0.01 \mathrm{~V}$ olt up to 0.6 Volt, the phase angle decreases from $-19.9^{\circ}$ down to $-69.6^{\circ}$, at $\mathrm{F}=200 \mathrm{kHz}$, as an example. Further increase in the bias voltage up to 1.2 Volts, shows that the phase angle almost constant. At a certain value of voltage (1.0 volts), as an 
example, the phase angle of both forward and reverse bias voltage increased from $-2.7^{\circ}$ and $67.2^{\circ}$ up to $-17.3^{\circ}$ and $-72.6^{\circ}$ measured at a signal frequency value of $50 \mathrm{kHz}$ and $300 \mathrm{kHz}$.

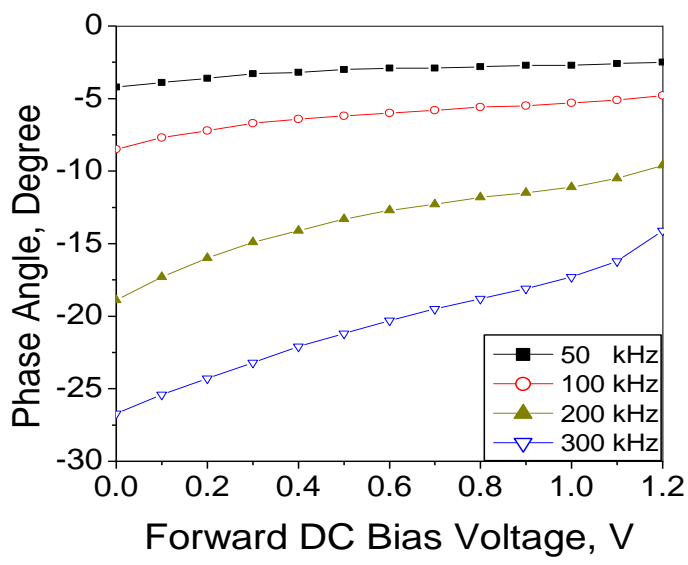

(a)

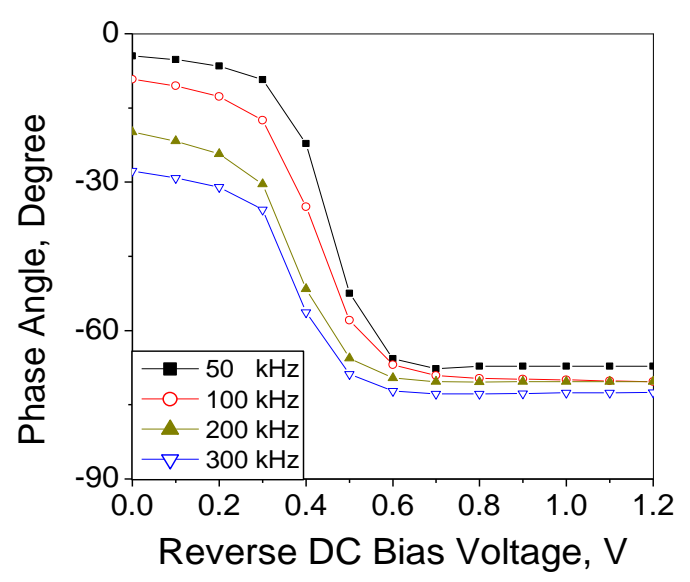

(b)

Fig. (7): Dependence of LED phase angle on forward (a)- and reverse (b)-bias voltages, plotted at different signal frequency values.

\section{2 (C-V) Characteristics of Phototransistor}

\subsubsection{Emitter Diffusion -and Collector Transition -Capacitances}

The capacitance-voltage relationships $(\mathrm{C}-\mathrm{V})$ of the emitter diffusion - and collector transition -capacitances of the phototransistor were studied at different frequency levels (Fig. 8). For the emitter junction, Fig. (8a) shows the forward emitter-base voltage dependence of the $C_{D}$, plotted as a function of different operating frequency values in the range from 100 $\mathrm{kHz}$ up to $300 \mathrm{kHz}$. It is clearly shown that, as an example, at frequency value of $200 \mathrm{kHz}$, $\mathrm{C}_{\mathrm{D}}$ increases as a function of the emitter-base bias voltage, where a value of $0.581 \mathrm{nF}$, measured at 0.01 Volt, increases up to $3.048 \mathrm{nF}$, measured at 0.80 Volt. Considering the frequency, it is clearly shown from the same figure that, for the same bias-voltage values, $C_{D}$ decreases as a function of frequency (El - Ghanam and Abdel Basit, 2011). Noting that $C_{D}$ is independent of the junction area, but it depends mainly on the diode current (Eq. 1). On the other hand, for the collector-base junction, Fig. (8b) shows the $(\mathrm{C}-\mathrm{V})$ relationship, plotted at four different frequency levels of $50 \mathrm{kHz}, 100 \mathrm{kHz}, 200 \mathrm{kHz}$, and $300 \mathrm{kHz}$. It is clearly shown that the collector transition capacitance is a function of both the reverse voltage and frequency (Eq. 2). As an example, at $200 \mathrm{kHz}$, a capacitance value of around $1.2985 \mathrm{nF}$, measured at bias voltage $\left(\mathrm{V}_{\mathrm{CB}}\right)$ of 0.01 Volt, decays rapidly as a function of the applied reverse voltage, where it reaches approximately a value of $0.01226 \mathrm{nF}$ at $\mathrm{V}_{\mathrm{CB}}$ value of 0.90 Volt. Considering the frequency, at a certain value of voltage of $0.6 \mathrm{Volt}, \mathrm{C}_{\mathrm{T}}$ decrease from $0.32 \mathrm{nF}$ down to $0.11 \mathrm{nF}$ as a frequency increased from $50 \mathrm{kHz}$ up to $300 \mathrm{kHz}$. 


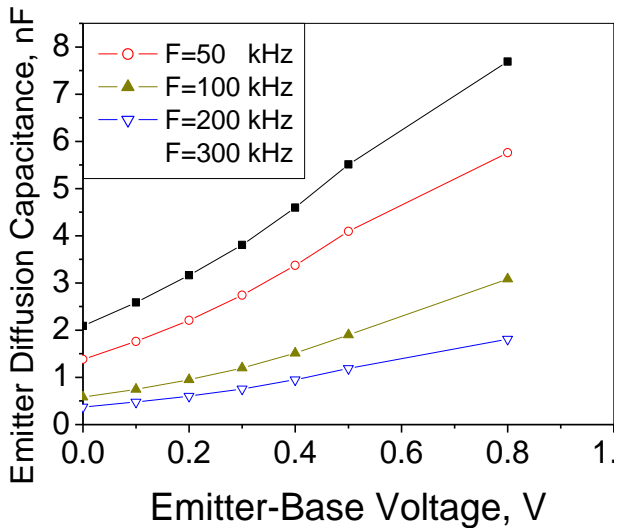

(a)

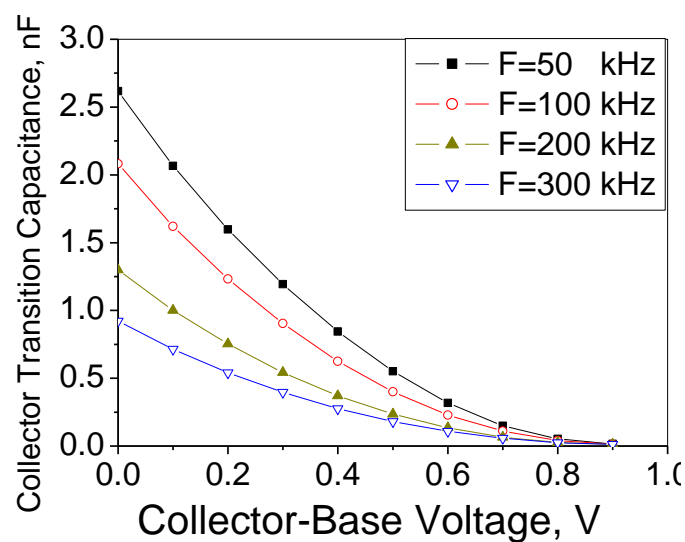

(b)

Fig. (8): Dependence of the emitter diffusion (a)-and (b) collector transition -capacitances on bias voltage, plotted at different frequency values.

\subsubsection{Impedance of Emitter -and Collector -base Junctions}

Considering the junctions impedance, it is clearly shown that for both junctions, their impedances are a functions of their bias voltage values (Fig. 9). For the emitter-base junction, the impedance value was shown to be function of forward bias voltage, while it could be considered independent of signal frequency (Fig. 9a). On the other hand, for the collectorbase junction, at low bias value range, from 0.01 Volt up to 0.7 Volt, the impedance value was shown to be independent on both the reverse bias voltage and frequency. But, for higher bias voltage values, it is proved that its dependence is shown to be pronounced (Fig. 9b), where its value increased from 10.33 up to 64.53 as a reverse bias voltage increased up to 0.9 Volt, and decreased as a frequency increased.

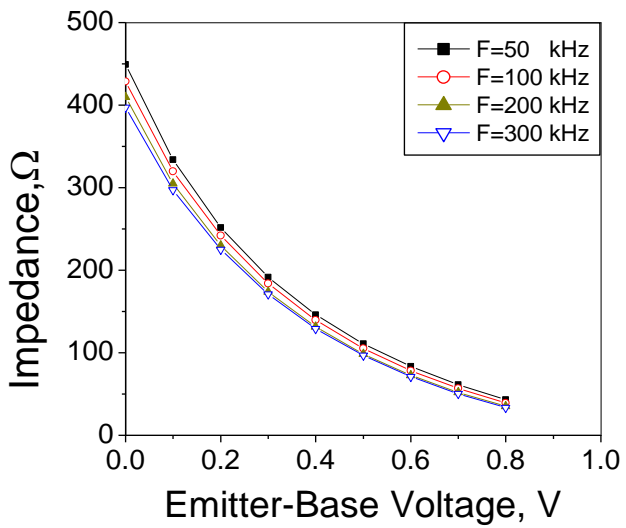

(a)

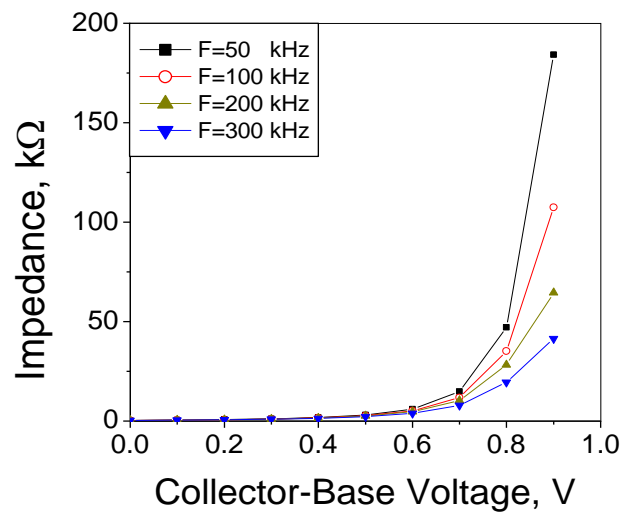

(b)

Fig. (9): Impedance-voltage relationships of phototransistor junctions plotted at different frequency values. 


\subsubsection{Quality Factor of Emitter -and Collector -Base-Junctions}

As have been mentioned before, the quality factor is a figure of merit of the transistor, and can be expressed as the ratio of the inductive and capacitance reactance of the junction to its resistance. In this concern, $\mathrm{Q}$ dependence on the junction bias was experimentally measured for the output phototransistor. Fig. (10) shows the Q-factor plotted as a function of both forward emitter-base voltage (Fig. 10a) and the reverse collector-base voltage (Fig. $10 \mathrm{~b})$, respectively. The measurements were carried out at different frequency values ranging from $50 \mathrm{kHz}$ up to $300 \mathrm{kHz}$. For the emitter-base junction, Q was shown to be decreased as the emitter-base forward voltage increased. Noting that for the forward emitter-base bias junction, Q was shown to be dependent on both the emitter bias voltage and signal frequency (Equ. 4). On the other hand, for the reverse collector-base mode, the quality factor shows lower dependence on the low bias voltage values up to 0.60 Volt. But, for higher bias voltage values, up to 0.90 Volt, $\mathrm{Q}$ shows, relatively, higher dependence on bias value. As an example, at frequency value of $200 \mathrm{kHz}, \mathrm{Q}$ was shown to increase from 0.987 , measured at bias voltage of 0.40 Volt, up to 2.74 , measured at bias voltage of 0.80 Volt.

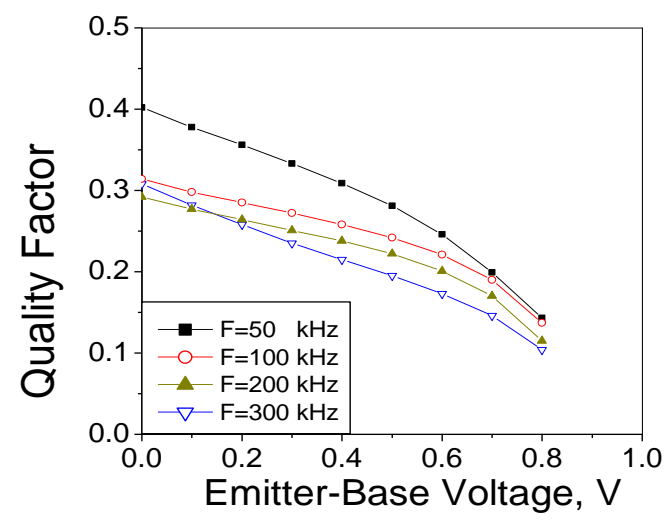

(a)

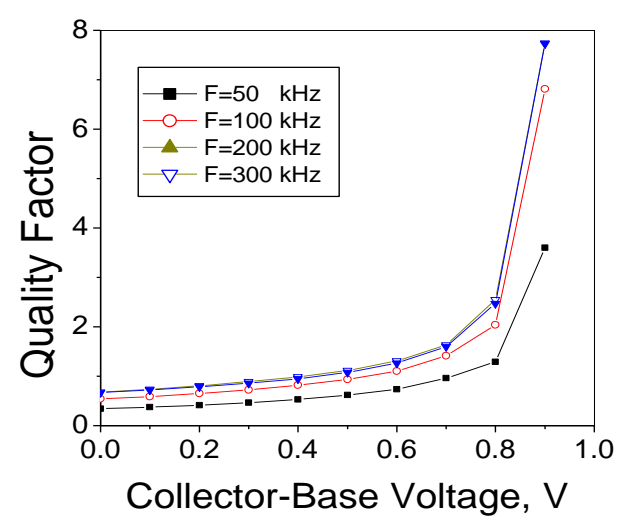

(b)

Fig. (10): Quality factor dependence on forward emitter-base bias (a) and voltage reverse collector-base bias voltage (b), plotted at different frequency values.

\subsubsection{Dissipation Factor of Emitter -and - Collector base-Junctions}

The dissipation factor (D) dependence on bias voltage for both the collector-base and emitter-base junctions of the phototransistor were plotted at different frequency values (Fig. 11). For the emitter-base junction, the value of the dissipation factor was proved to be an increasing function of both forward voltage and frequency (Fig. 11a). On the other hand, for the reverse biased collector-base junction (Fig. 11b), it is clear that the value of D is a decreasing function of both the reverse voltage and frequency. As an example, for a signal of $200 \mathrm{kHz}$, a dissipation factor value of 1.498 , measured at 0.01 Volt, decreases rapidly as a function of the applied reverse voltage value, where it reaches approximately a value of 0.101 , measured at bias value of 0.79 Volt. 


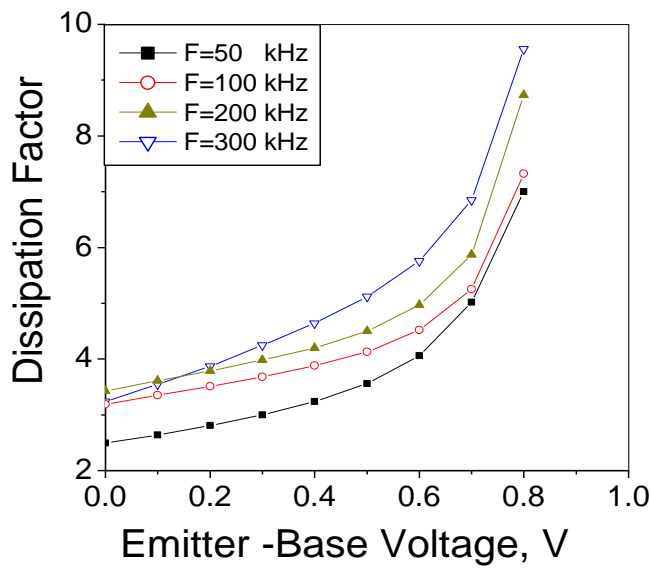

(a)

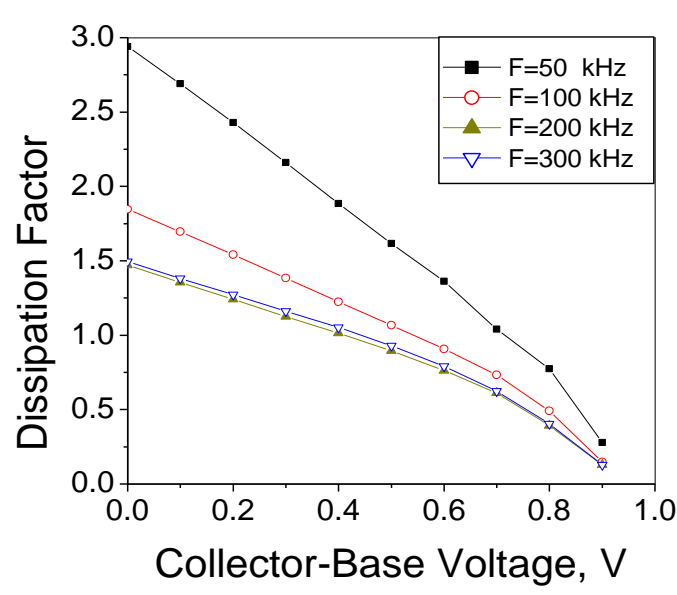

(b)

Fig. (11): Dependence of the dissipation factors on forward emitter-base bias voltage (a) and reverse collector-base bias voltage (b), plotted at different frequency values.

\subsubsection{Phase Angle of Emitter -and Collector -Base-Junctions}

The phase angle $(\Phi)$ is the angle between the current passing through the junction and the applied voltage, and is given by the ratio of the total reactance to the total ohmic resistance of the junction. In this concern, Fig. (12) shows the dependence of $\Phi$ on bias voltage for the forward emitter-base junction and the reverse collector-base junction, plotted at different frequency levels. For the emitter-base junction (Fig. 12a), $\Phi$ was plotted as a function of the forward bias voltage, where it is clearly shown that, it represents a decreasing function of both the forward bias voltage and signal frequency. At $\mathrm{F}=200 \mathrm{kHz}$, its value was shown to increase from $-16.2^{\circ}$, measured at 0.01 Volt, up to $-6.5^{\circ}$, measured at $0.80 \mathrm{Volt}$. On the other hand, for the reverse junction, it is clear that, for the bias voltage range from 0.01 Volt up to around 0.90 Volt, $\Phi$ was slightly increased, that is at $200 \mathrm{kHz}, \Phi$ value of $-33.7^{\circ}$, measured at 0.01 Volt changes up to $-84.2^{\circ}$, measured at applied value of 0.90 Volt. As well, $\Phi$ was shown to be direct increasing function of the signal frequency (Fig. 12b). Noting that, $\Phi$ is governed by the following equation (El - Ghanam and Abd el Basit, 2011):

$$
\tan \theta=\frac{X_{c}}{R}
$$




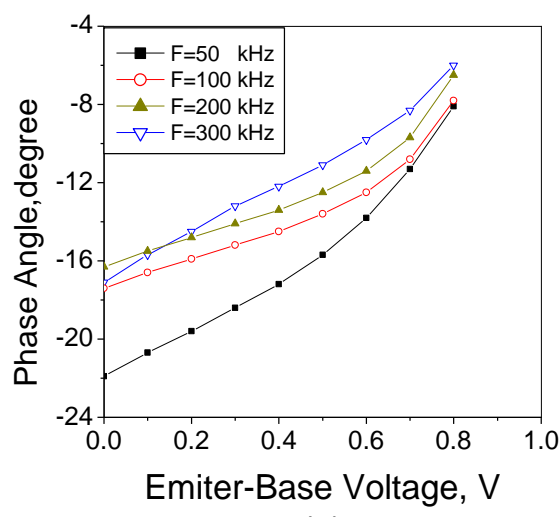

(a)

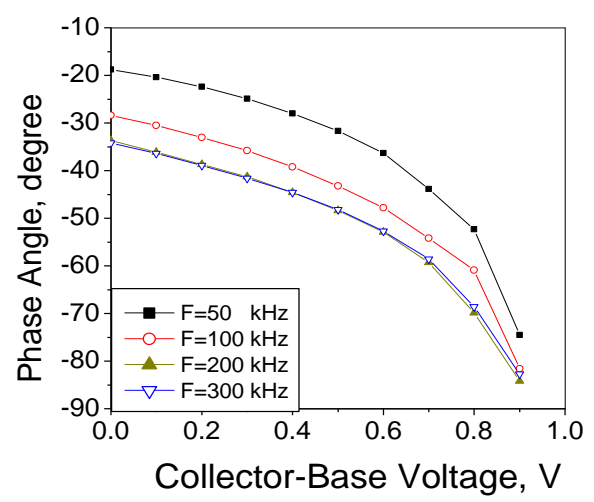

(b)

Fig. (12): Phase angle versus emitter-base bias voltage (a) and collector-base bias voltage (b), plotted at different signal frequency values.

\section{Conclusion}

In this paper, a detailed experimental study, and analysis of the junction capacitance characteristics $(\mathrm{C}-\mathrm{V})$ of the input LED and output phototransistor of the well known 4N25 optocupler were presented. From which, it is clearly shown that for both devices, and in turn the optocoupler itself, their capacitive characteristics are a direct functions of the operating conditions, from which are the biasing voltage and frequency.

\section{References:}

Bogdan. M, Wilamowski.J, and Irwin.D, "Fundamentals of Industrial Electronics", $2^{\text {nd }}$ Ed., Ch. 8, CRC Press, USA, 2011.

Boylestad. L. R and Nashelsky.L, "Electronic Devices and Circuits Theory", $7^{\text {th }}$ Ed., Ch. 1, Granite Hill Publishers, USA, 1999.

Chin Wey-Long, et al., "EMI Prevention of CAN-Bus-Based Communication in Battery Management Systems", Intr. Jour. of Eng. \& Computer Sciences: IJECS-IJENS, Vol. 13, No. 05, pp. 6-12, October 2013.

Chouthai .A, Karhu .R and Kulkarni .S, "RPM measurement and calculations using TSOP IR receiver", Intr. Jour. of Advanced Research in Electrical, Electronics and Instrumentation Engineering, Vol. 2, No. 7, July 2013.

Dutta .S, Kamilya .T and Samanta. S. K, "A simple method to measure the depletion capacitance of a schottky junction diode", Jour. of Physical Sciences, Vol. 17, pp. 197200, 2013.

Dyer .S. A, "Wiley Survey of Instrumentation and Measurement", John Wiley \& Sons, USA, 2001.

Eugene C. C. and Lee, Jose. S," Optocoupler current transfer ratio temperature compensation 
method and apparatus", United States Patent, Patent N0.: US 7,582,887 B1, Sep. 1, 2009.

Ghanam. S. M and Abdel Basit. W, "Performance of electronic switching circuits based on bipolar power transistors at low temperature", Cryogenics, Vol. 51, No. 3, pp. 117-123, 2011.

Godse .A.P and Bakshi .U.A., "Electronic circuits", $1^{\text {st }}$ Ed., Technical Publications Pune, India, 2008.

Hopcroft. M. A, et al., "Using the temperature dependence of resonator quality factor as a thermometer ", Appl. Phys, Vol. 91, No. 1, pp. 013505-1 to 013505-3, 2007.

Kim .Ch. H., et al., "Capacitive behavior of pentacene - based diodes: Quasistatic dieelectric

constant and dielectric strength", Jour. of Applied Physics, American Institute of Physics,Vol.109, No. 8, pp. 083710 - 083710-9, 2011.

Lei Tian and Xinquan Lai, "Research of high-speed and stable photodetector of Mono-lithic Optocoupler Chip", Intr. Jour. of Signal Processing, Image Processing and Pattern Recognition, Vol.7, No.2, pp.177-186, 2014.

Reed .R.A, et al., "Emerging optocoupler issues with energetic particle-induced transient and

permanent radiation degradation ", IEEE Trans. on Nuclear Science, Vol. 45, No. 6, pp.2833-2841, December 1998.

Reed. R. A, Marshall. P. W. and Label. K. A, "Space radiation effects in optocouplers", Intr. Jour. of High Speed Electronics and Systems, Vol. 14, No. 2, pp. 401-417, 2004.

Rodahl. M, et al., "Quartz crystal micro-balance setup for frequency and Q - factor measurements in gaseous and liquid environments", Rev. Sci. Instrum., American Inst. of Physics, Vol. 66, No. 7, pp. 3924 - 3930, July 1995.

Yao.Y, et al., "Low voltage and fast speed all-polymeric optocouplers", Applied Phys. Letters, Vol. 90, No. 5, pp. 053509-1 - 053509-3, 2007. 


\section{المخلص باللغة العربية}

\section{اعتماد خصائص وصلة نبائط المزدوج الضوئى على ظروف التثغيل}

وفاء عبد الباسط عبد الرحمن زكرى(1) ـ ورده حسن عبد الله حسن(1) ـ فؤاد عبد المنعم

سعد سليمان(2) ـ ثناء عبد التواب قمح(1)

1 ـمعمل أبحاث الإكترونيات ـ قسم الفيزياء ـ كلية البنات للأداب و العلوم والتربية ـ جامعة عين شمس ـ

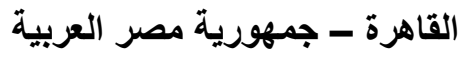

r ـ هيئة المواد النووية ـ صندوق بريد 530- المعادى 11728 ـ القاهرة - جمهورية مصر العربية

يهدف هذا البحث إلى إلقاء الهزيد من الضوء على إعتماد خصائص وصلة نبيطة المزدوج الضوئى المقترح طر از 4N25 على ظروف التشغيل من جهد مطبق وتردد الإشارة. وفي هذا الصدد فقد تم دراسة ورسم كافة الخصائص الكهربية للنبيطه الثنائي الباعثة للضوء (دخل المزدوج الضوئُ) ولنبيطة التزانزستور الضوئي (خرج المزدوج الضوئى)

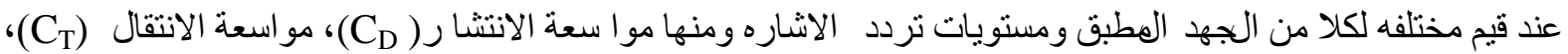
الاعاقه (Z) )، معامل الجوده (Q)، معامل الفق (D) وزاوية فرق الطور(D) وذللك فى حالتى الانحياز الامامى و العكسى . ـ فيما يتعلق بللنيطة الثنائي الباعثة للضو ء، فقه أظهرت النتائج انه عند ثبوت تردد الاشاره عند قيمه معينه تساوى 200 4.71 nF 0.166 nF لى سلى سبيل المثال، فان مواسعة الانتشار تزداد كداله اسيه فى جهد الانحياز المطبق من مقاسه عند قيم للجهود تساوى 0.01 و 1.20 Volts على التو الى. كما ثبت انة حال تطبيق قيمه معينه من الجهد

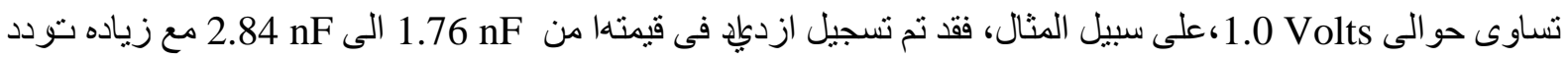
200 kHz الاشاره من 200 kHz 30 kHz و على الجانب الاخر و عند ثبوت تردد الاشاره عند قيمه معينه تساوى ، على سبيل المثال، فان قيم مو اسعة الانتقال تقل سريعا من 178.36 مقاسه عند جهد يساوى 30.42 Volt 0.01 الى مقاسه عند جهد يساوى pF 0.3 Volt كما ثبت انة حال تطبيق جهد انحياز اعلى، فأن الانخفاض فى قيمة المواسعة يكاد يكون غير ملحوظ. كما تم تسجيل انة عند قيمه معينه من الجهد يساوى 1.0 Volt،على سبيل المثال، فان قيمة

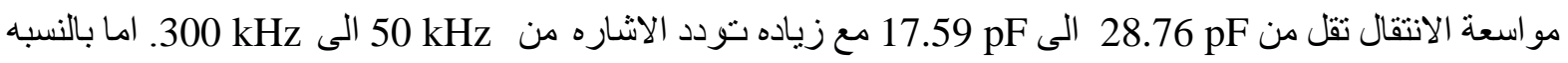
الى نبيطة النرانزستور الضوئي، فقد ثبت ان قيمه مواسعة وصلة الباعث تزداد كدالة اسية مع الجهود المطبقة على وصلة

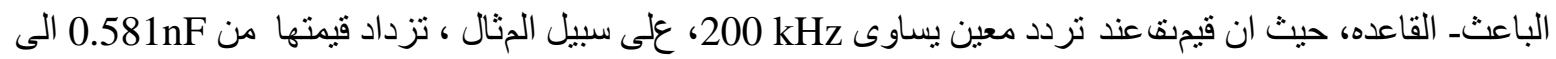

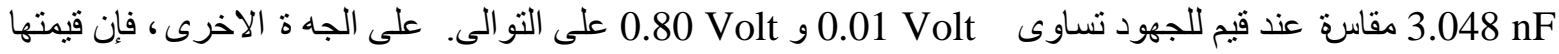
تضمحل سريعا كدالة فى جهد الانحياز العكسى المطبق ، حيث تقل قيمته من 0.012 nF 1.29 مقاسة عند قيم

للجهود تساوى Volt 0.01 Volt 0.8 على التو الى. اما بالنسبة الى اعتماد المو اسعتين السابقتين على تردد الاشارة، فإنه عند قيمة معينة من الجهود المطبقه تساوى 0.8 Volt لوحظ ان قيمتهما تقل من nF 0.053 nF 1.8 . 0.03 nF gnF 